Jurnal HELPER, Vol 35 No 2 (2018) 05 - 11

Bimbingan dan Konseling Universitas PGRI Adi Buana Surabaya

ISSN: 02162938

\title{
PENGARUH TEKNIK INFORMASI DALAM BIMBINGAN KELOMPOK TERHADAP PERENCANAAN KARIER SISWA KELAS IX MTS HASANUDDIN SIDOARJO
}

\author{
Maghfirotul Lathifah \\ (Dosen Program Studi Bimbingan dan Konseling, Fakultas Keguruan dan Ilmu Pendidikan, \\ Universitas PGRI Adi Buana Surabaya) \\ maghfirotul@unipasby.ac.id \\ Nita Nurqoidah \\ (Bimbingan dan Konseling, Fakultas Keguruan dan Ilmu Pendidikan, \\ Universitas PGRI Adi Buana Surabaya) \\ nitanurqoidah@gmail.com
}

\begin{abstract}
Abstrak
Penelitian ini bertujuan untuk mengetahui signifikansi pengaruh Teknik Informasi dalam Bimbingan Kelompok Terhadap Perencanaan Karier Siswa Kelas IX MTs Hasanuddin Sidoarjo. Jenis penelitian ini kuantitatif dengan menggunakan one group pre-test post-test design. Sampel yang digunakan dalam penelitian ini adalah 6 siswa dari kelas IX yang memiliki perencanaan karier rendah. Hasil perhitungan pre-test dan post-test menunjukkan adanya peningkatan perencanaan karier siswa dilihat dari hasil pre-test 48.66 dan hasil post-test meningkat sebesar 56.50 Dari hasil uji Wilcoxon dengan Asymp. Sig (2-tailed) sebesar 0.046, maka Ha diterima. Dengan demikian, maka dapat disimpulkan bahwa adanya pengaruh yang signifikan teknik informasi dalam bimbingan kelompok terhadap perencanaan karier siswa kelas IX MTs Hasanuddin Sidoarjo terhadap perencanaan karier siswa setelah diberikan teknik informasi dalam bimbingan kelompok.

Kata Kunci: Teknik Informasi, Bimbingan kelompok, Perencanaan Karier
\end{abstract}


Jurnal HELPER, Vol 35 No 2 (2018) 05 - 11

Bimbingan dan Konseling Universitas PGRI Adi Buana Surabaya

ISSN: 02162938

\begin{abstract}
This study aims to determine the significance of the influence of Information Techniques in Group Guidance on Career Planning for Class IX Students of MTs Hasanuddin Sidoarjo. This type of research is quantitative by using one group pre-test post-test design. The sample used in this study was 6 students from class IX who had low career planning. The results of the pre-test and post-test calculations showed an increase in student career planning seen from the 48.66 pre-test results and the post-test results increased by 56.50 from the Wilcoxon test results with Asymp. Sig (2-tailed) of 0.046, then Ha is accepted. Thus, it can be concluded that there is a significant influence of information techniques in group guidance on career planning of class IX students of MTs Hasanuddin Sidoarjo on students' career planning after being given information techniques in group guidance.
\end{abstract}

Keywords: Information Engineering, Group Guidance, Career Planning

\section{LATAR BELAKANG}

Masa remaja merupakan fase kehidupan yang sangat penting dalam siklus perkembangan individu, karena mengarah pada masa dewasa yang sehat. Masa ini menunjukkan dengan jelas sifat masa transisi dari status kanak-kanak menuju dewasa. Banyak masalah yang muncul pada masa remaja ini, salah satunya masalah kesipan karier. Hal ini menjadi konsekuensi logis dari perkembangan remaja dimana terdapat tuntutan bagi yang mempersiapkan karier.

Permasalahan karier yang terjadi pada remaja biasanya berkaitan dengan pemilihan jenis pendidikan, yang mengarah pada pemilihan jenis pekerjaan dimasa depan. Permasalahan ini sangat penting untuk diperhatikan kariern dengan banyaknya kebinggungan yang dialami remaja dalam menentukan arah kariernya Lestari (2017: 27).

Penelitian yang dilakukan oleh Nofian (2016: 21) di kelas X SMAN 1 Padang berdasarkan hasil rekapitulasi penelitian didapatkan keterangan bahwa ada peserta didik yang tidak pernah mengalami masalah dalam perencanaan karier dan juga ada peserta didik yang mengalami masalah dalam perencanaan karier, serta memerlukan bantuan pengentasan masalah yang salah satunya dapat dilakukan oleh guru BK melalui pelayanan bimbingan karier.

Siswa masih sering berkunjung ke ruang bimbingan dan konseling untuk bertanya mengenai cara memilih dan merencanakan karier yang tepat untuk mereka. Siswa mengaku bingung dalam merencanakan karier dan halhalyang harus mereka lakukan setelah lulus SMA. Sedangkan guru bimbingan dan konseling hanya memberikan informasi melalui papan informasi yang ada, Ummah (2013: 19).

Rendahnya perencanaan karier siswa menimbulkan kebingungan dalam memilih karier yang diinginkan, banyaknya siswa yang masih bertanya-tanya akan perencanaan Karier 
Jurnal HELPER, Vol 35 No 2 (2018) 05 - 11

Bimbingan dan Konseling Universitas PGRI Adi Buana Surabaya

ISSN: 02162938

yang akan ditujuh dan banyak menimbulkan pengangguran bagi siswa yang baru lulus atau tidak bisa memaksimalkan kemampu pada dirinya.

Menurut Sukardi (1987: 96) dalam perkembangan karier seseorang dipengaruhi oleh beberapa faktor, diantaranya faktor internal dan eksternal. Faktor internal yaitu berasal dari diri individu itu sendiri yang meliputi bakat, minat, kepribadian, serta potensi-potensi lainnya. Sedangkan faktor eksternal yaitu faktor-faktor sosial atau faktor yang berasal dari luar diri individu tersebut, seperti lingkungan keluarga dan lingkungan masyarakat yang ikut memegang peranan penting dalam proses perkembangan karier.

Menurut Ndungu'u

(2008:12)

Perencanaan adalah aspek-aspek penting dari pendidikan karena konselor membantu siswa yang ingin merencanakan Karier di masa depan. Aspirasi karier dalam kebanyakan kasus membingungkan terhadap tekanan, dan kurangnya informasi karier terutama banyak mata pelajaran yang ditawarkan di sekolah. Siswa masih membutuhkan bimbingan dari konselor sekolah dan bimbingan karier orang tua.

Proses ini sangat penting bagi para individu untuk mencari mata pelajaran di sekolah atau jurusan di perguruan tinggi. Sedang memilih mata pelajaran dan jurusan tertentu, kebanyakan dari mereka tidak membutuhkan permainan dan informasi ini sangat penting bagi siswa.

Bimbingan karier dapar diberikan melalui berbagai cara dan bentuk layanan salah satunya yakni layanan informasi karier. Menurut Hariastuti (2008: 28) layanan informasi yaitu layanan yang bertujuan untuk membekali seseorang dengan berbagai hal yang berguna untuk mengenal diri, merencanakan dan mengembangkan pola kehidupan sebagai pelajar, anggota keluarga dan masyarakat.

Sedangkan menurut Sukardi (1987: 113) menyatakan bahwa informasi karier adalah salah satu alat yang dipergunakan untuk membantu siswa dalam memahami dirinya, dunia kerja pada umumnya, serta aspek-aspek kerja siswa dalam merencanakan kariernya dengan tepat, sesuai dengan bakat, minat, kemampuan, pengetahuan dan kepribadian, serta faktor-faktor yang mendukung kemajuan dirinya. Faktor-faktor yang mendukung kemajuan diri tersebut, misalnya informasi seputar karier yang diperoleh siswa dan status sosial ekonomi orang tua siswa.

Romlah (2006: 87) berpendapat bahwa teknik pemberian informasi sering juga di sebut metode ceramah, yaitu pemberian penjelasan oleh seorang pembicara kepada sekelompok pendengar. sebenarnya pemberian informasi tidak hanya diberikan secara lisan, tetapi juga dapat diberikan secara tertulis. Pemberian informasi secara tertulis dapat dilakukan 
Jurnal HELPER, Vol 35 No 2 (2018) 05 - 11

Bimbingan dan Konseling Universitas PGRI Adi Buana Surabaya

ISSN: 02162938

melalui berbagai medi, misalnya papan bimbingan, majalah sekolah, rekaman (tape recorder), selebaran, video dan film. Pelaksanaan teknik pemberian informasi mencakup tiga hal, yaitu: perencanaan, pelaksanaan, dan penilaian. (Jacobsen, dkk., 1985). Pada tahap perencanaan, terdapat tiga langkah yang harus diperhatikan yaitu;

a. Merumuskan tujuan apa yang hendak di capai dengan pemberian informasi

b. Menentukan bahan yang akan di berikan apakah berupa fakta, konsep atau generalisasi

c. Menentukan dan memilih contoh-contoh yang tepat sesuai dengan bahan yang di berikan.

Tahap pelaksanaan, menyajikan materi disesuaikan dengan tujuan yang hendak dicapai. Apabila tujuannya untuk mengajarkan fakta, maka tugas pemberian informasi adalah membuat bahan itu yang mudah diingat oleh siswa atau pendengar. Tahap terakhir pemberian informasi adalah mengadakan penilaian apakah tujuan sudah tercapai ataupun belum. Penilaian dapat dilakukan secara lisan dengan menanyakan pendapat siswa mengenai materi yang di terima, tetapi dapat juga dilakukan secara tertulis baik dengan tes subjektif ataupun objektif.

Melihat dari beberapa permasalah yang dialami siswa SMA peneliti ingin mengaji penelitian yang berhubungan perencanaan
Karier siswa di MTs daerah Sidoarjo, karena ada peneliti ingin mengetahui apakah dikota besar seperti Sidoarjo para siswa MTs mempunyaui perencanaan Karier dalam dirinya sendiri atau mereka hanya mengikuti apa kata orang sekitarnya.

Disini peneliti ingin mengaji di sekolah MTs swasta karena peneliti ingin mengentahui apakah di sekolah swasta siswanya memiliki rancangan setelah lulu dari MTs akan lanjut ke jenjang mana lagi. Tidak hanya itu dari beberapa kasus yang sudah terterah di siswa SMA masih bingung untuk merencanakan kariernya di jenjang yang lebih tinggi atau mau langsung kerja. Dengan adanya masalah di SMA peneliti ingin melakukan penelitian di jenjang yang lebih rendah yaitu di MTs, Seberapa matang mereka merencanakan kariernya, sehingga siswa yang ingin melanjutkan ke jenjang SMA/SMK/MA tidak sulit untuk menentukan kariernya.

\section{METODOLOGI}

Penelitian ini menggunakan penelitian pra-eksperimental dengan menggunakan pendekatan kuantitatif. Desain penelitian yang digunakan adalah One Group Pre-Test PostTest Design. Penelitian ini dilaksanakan di MTs Hasanuddin Sidoarjo.

Populasi penelitian ini ialah seluruh siswa Siswa Kelas IX MTs Hasanuddin Sidoarjo. Penelitian sampel dalam penelitian ini menggunakan teknik purposive sampling yaitu 
Jurnal HELPER, Vol 35 No 2 (2018) 05 - 11

Bimbingan dan Konseling Universitas PGRI Adi Buana Surabaya

ISSN: 02162938

teknik penentuan sampel dengan pertimbangan tertentu. Sampel penelitian ini ialah 6 orang yang memiliki perencanaan karier rendah.

Variabel bebas dalam penelitian ini yaitu teknik informasi karier dalam bimbingan kelompok, sedangkan variabel terikat dalam penelitian ini yaitu perencanaan karier siswa. Instrument penelitian yang digunakan adalah observasi dan skala pengukuran.

Metode pengumpulan data yang digunakan dalam penelitian ini adalah observasi dan skala pengukuran. Pengujian dalam penelitian ini adalah dengan menggunakan teknik analisis non-parametrik. Hasil uji Wilcoxon diperoleh nilai 0.046 yang berarti si > 0,05 .

\section{HASIL PENELITIAN}

Penggunaan teknik informasi dalam bimbingan kelompok berpengaruh untuk meningkatkan perencanaan karier siswa. Hal ini ditunjukkan dengan hasil Asymp (2-tailed) bernilai 0.046 . Karena nilai 0.046 lebih kecil < 0,05, maka dapat disimpulkan bahwa $H_{a}$ diterima. Artinya ada perbedaan antara perencanaan karier untuk Pre-test dan Post-test, sehingga dapat disimpulkan pula bahwa ada pengaruh yang signifikansi antara teknik informasi dalam bimbingan kelompok terhadap perencanaan karier siswa kelas IX MTs Hasanuddin Sidoarjo.

Hasil penelitian ini dapat terlaksana dengan baik karena adanya media yang digunakan oleh peneliti, yakni dengan menggunakan slide PowePoint, menggunakan audio visual (video) dan evaluasi. Penggunaan slide PowePoint yang menarik merupakan salah satu cara penyampaian teknik informasi kepada siswasiswa dalam pemilihan karier mereka. Pemberian treatment dengan media slide PowePoint berlangsung selama 3 kali pertemuan. Pemberian informasi dengan audio visual (video) dilaksanakan dengan cara mencari video inspiratif tentang karier di youtube. Teknik audio visual (video) merupakan salah satu cara agar siswa antusias dalam belajar tentang karier. Pemberian informasi dengan audio visual (video) ini berlangsung selama 3 hari. Di pertemuan ke 7 , dilakukan evaluasi tentang pertemuanpertemuan sebelumnya, tanya jawab, refleksi perasaan, tentang apa saja pencapaian oleh siswa-siswa dan kesan pesan oleh konselor dan siswa-siswa.

Setelah dilakukan treatment tersebut, siswa-siswa dapat melaksanakan syarat-syarat dalam memilih kariernya. Menurut Manhiru (1992), ada 3 syarat dalam memilih karier, yakni: (1) Pemeriksaan dan pengenalan nilainilai pribadi (the deciding self),

Pengetahuan dan penggunaan informasi yang akurat dan relevan (sebelum memutuskan), (3) Pengetahuan penggunaan strategi untuk mengkonversikan informasi kedalam tindakan.

\section{KESIMPULAN}


Jurnal HELPER, Vol 35 No 2 (2018) 05 - 11

Bimbingan dan Konseling Universitas PGRI Adi Buana Surabaya

ISSN: 02162938

Berdasarkan hasil penelitian "pengaruh teknik informasi dalam bimbingan kelompok terhadap perencanaan karier siswa kelas IX MTs Hasanuddin Sidoarjo."Maka dapat ditarik kesimpulan bahwa teknik informasi dalam bimbingan kelompok pada siswa kelas IX MTs Hasanuddin Sidoarjo sangat berpengaruh dalam bimbingan kelompok, responden dapat meningkatkan perencanaan karier siswa, yang semula dalam kategori rendah menjadi tinggi.

Dari hasil perhitungan menggunakan teknik statistika non-parametrik uji Wilcoxon diperoleh statistik deskriptif perencanaan karier siswa. Dari hasil analisis data tersebut, diperoleh hasi bahwa terjadi peningkatan nilai rata-rata (mean) score variabel perencanaan karier siswa pada $\mathrm{N}=6$. Nilai mean sebelum diberikan teknik informasi 48.6667dengan nilai standar deviasi sebesar0.51640. Sedangkan setelah diberikan teknik informasi nilai mean meningkat menjadi 56.50 dengan standar deviasi sebesar 7.29. Hasil interpretasi menggunakan uji Wilcoxon diketahui bahwa Asymp.Sig. (2-tailed) bernilai 0.046. Karena nilai 0.046 lebih kecil < 0.05, maka dapat disimpulkan bahwa $\mathrm{H}_{\mathrm{a}}$ diterima. Artinya ada perbedaan antara perencanaan karier untuk Pretest dan Post-test, sehingga dapat disimpulkan pula bahwa "Ada Pengaruh yang signifikansi antara teknik informasi dalam bimbingan kelompok terhadap perencanaan karier siswa kelas IX MTs Hasanuddin Sidoarjo.”
Saran yang diajukan adalah sebagai berikut:

1. Bagi siswa kelas IX MTs Hasanuddin Sidoarjo agar lebih aktif dalam mencari informasi ke guru bimbingan dan konseling tentang karier yang akan dicapai, karena siswa haruslah aktif dan bertanggung jawab atas dirinya.

2. Bagi guru bimbingan dan konseling MTs Hasanuddin Sidoarjo agar lebih mengoptimalkan bimbingan kelompok dengan layanan informasi karier menggunakan audio visual/media-media yang kreatif, sehingga siswa menjadi tertarik dalam mengikuti kegiatan bimbingan kelompok.

3. Bagi peneliti lain yang tertarik dengan tema penelitian ini agar dicoba diaplikasikan ke sekolah lain ataupun jenjang lain misalnya SMA/SMK/SMK dengan teknik ataupun cara yang lebih kreatif lagi.

\section{DAFTAR PUSTAKA}

Atmaja, Twi Tandar. (2014). Upaya Meningkatkan Perencanaan Karier Siswa Melalui Bimbingan. Karier Dengan Penggunaan Media modul. Universitas Ahmad Dahlan.

Australian Journal of Career Development Winter 2001, Vol. 10 (2), pp. 11-14Sweet, Richard. Career information, guidance and counselling services: Policy perspectives.

Hariastuti, Tri Retno. (2008). Dasar-Dasar Bimbingan dan Konseling. Surabaya: Unesa University Press. 
Jurnal HELPER, Vol 35 No 2 (2018) 05 - 11

Bimbingan dan Konseling Universitas PGRI Adi Buana Surabaya ISSN: 02162938

Hartono. (2016). Bimbingan Karier.

Yogyakarta: Prenada Media Grup.

Lestari, Indah. (2017). Meningkatkan Kematangan Karier Remaja Melalui Bimbingan Karier Berbasis Life Skills. Skripsi. Universitas Muria Kudus.

Magnusson, Kris. (2015). Five Processes of Career Planning. Simon Fraser University. Journal of Education and Practice ISSN 2222-1735 (Paper).

Manhiru, Mohammad Thayeb. (1992). Pengantar Bimbingan dan Konseling Karir. Jakarta: Bumi Aksara

Ndug'u, mgumi owen. (2008). The role of career guidance and counseling in caree awareness and planning among public. Egerton University.

Permadi, Nofianti Eka. (2016). MasalahMasalah Yang Dihadapi Peserta Didik Dalam Perencanaan Karier Dan Implikasinya Terhadap Pelayanan Bimbingan Karier. Skripsi. Universitas Negeri Padang.
Romlan, Tatiek. (2006). Teori Dan Peraktek Bimbingan Kelompok. Universitas Negeri Malang.

Sukardi, D. K dan Sumiati, D. M. (1993). Panduan Perencanaan Karier. Surabaya: Usaha Nasional.

Sukardi, Dewa K. (1987). Bimbingan karier di sekolah-sekolah. Jakarta: Balai Aksara Yudhistira Saadiyah.

Suryabrata, Sumadi. (2015). Metodologi Penelitian. Jakarta: Rajawali press.

Ummah, Mukhtarul. (2013). Tentang Penerapan Layanan Informasi Karier Untuk Meningkatkan Kemampuan Perencanaan Karier Siswa Kelas XII SMAN I Krembung Sidoarjo. Skripsi. Universitas Negeri Surabaya.

Winkel, W.S dan Hastuti, Sri. (2004). Bimbingan dan Konseling di Institusi Pendidikan. Yogyakarta: Media Abadi. 